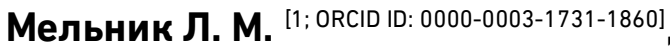
к.е.н., доцент,

Дума В. Л. ${ }^{[2]}$, к.е.н., менеджер,

Яковчук О. В. ${ }^{[1]}$, здобувач вищої освіти другого (магістерського) рівня

'Національний університет водного господарства та природокористування, м. Рівне, ${ }^{2}$ КБ «Приватбанк», м. Рівне

\title{
РОЛЬ ЗАОЩАДЖЕНЬ НАСЕЛЕННЯ У ФОРМУВАННІ ІНВЕСТИЦІЙНОГО ПОТЕНЦІАЛУ КРАЇНИ
}

В статті розглянуто теоретико-методичні аспекти формування інвестиційного потенціалу країни. Виокремлено внутрішні, зовнішні та змішані джерела формування інвестиційних ресурсів. Визначено сутність заощаджень населення та проведено їх класифікацію залежно від форм i фінансових інструментів. Проаналізовано передумови формування ощадної поведінки населення. Досліджено структуру капітальних інвестицій за джерелами фінансування. Надано пропозиції щодо покращення механізму формування заощаджень населення задля розширення інвестиційного потенціалу краӥни.

Ключові слова: заощадження населення; доходи населення; інвестиційний потенціал; капітальні інвестиції; банківські депозити.

Вирішення проблеми формування внутрішніх джерел інвестування неможливе без мобілізації вільних грошових ресурсів населення. Заощадження населення виступають потужним джерелом формування банківського капіталу, основою розвитку ринку цінних паперів та страхового ринку, сприяють зміцненню реального сектора економіки.

Заощадження населення, як економічне явище, концентрують в собі задоволення економічних інтересів не тільки окремих громадян і організацій, що надають фінансові послуги, а й держави в цілому. Також заощадження відіграють важливу роль при вирішенні проблем соціального характеру, оскільки виступають безпосереднім індикатором рівня життя і добробуту населення. Таким чином, становлення i розвиток ринкових відносин багато в чому визначаються ощадно-інвестиційною активністю населення і ефективністю використання його фінансових можливостей.

Водночас використання заощаджень населення для забезпечення формування інвестиційного потенціалу обмежується 
низкою негативних тенденцій у вітчизняній економіці. Високий рівень безробіття і низька продуктивність праці, скорочення доходів від трудової діяльності, значний міграційний відплив робочої сили призводять до зниження життєвого рівня працівників та їх сімей, до погіршення загальної соціально-економічної ситуації в країні.

Тому актуальним завданням, що постає перед вітчизняною економікою, $€$ акумулювання вільних грошових коштів населення, розробка ефективного механізму їх трансформації в інвестиційний ресурс для забезпечення довгострокового кредитування виробничого сектору.

Фінансова поведінка населення, процес формування заощаджень були предметом вивчення усіх найвідоміших шкіл економічної теорії. Дослідженням окремих аспектів формування та стимулювання заощаджень займалися такі зарубіжні та вітчизняні науковці, як Бадіда М. П., Бандура А. В., Бочаров В. В., Вовк О. М., Дж. Кейнс, Крамов Р. О., Кучерук Г. Ю., Макконел К. Р., А. Маршалл, Мірошниченко П. І., Ф. Модільяні, Нечитайло У. П., А. Сміт, М. Фрідмен та багато інших. Формуванню інвестиційного потенціалу економіки присвячені праці таких вчених, як Буряковський В. В., Гітман Л., Каламбет С. В., Литюга Ю. В., Тумусов Ф. С., Титаренко Н. О., Поручник А. М., Туріянська М. М., Шаблій О. І., Шаблій 3. О. та чимало інших. Разом з тим, питання обґрунтування ролі заощаджень населення в інвестиційному процесі країни вважаються дискусійними і вимагають подальших теоретико-методичних розробок, що визначає актуальність обраної теми.

Метою цієї статті є обґрунтування теоретичних та практичних засад формування заощаджень населення та їх впливу на інвестиційний потенціал країни.

В умовах соціально-економічної нестабільності існує низка проблемних аспектів щодо покращення інвестиційного потенціалу країни, яке, в свою чергу, можливе при ефективному формуванні інвестиційних ресурсів. Оскільки зовнішніх інвестиційних ресурсів недостатньо для сталого розвитку інвестиційного потенціалу країни, важливо звернути увагу на формування не менш важливих внутрішніх інвестиційних ресурсів - заощаджень населення.

Говорячи про сутність інвестиційного потенціалу, слід зазначити, що наразі немає єдиного тлумачення цього поняття, оскільки даний термін є багатогранним з точки зору економічного змісту, структури та взаємозв'язку з іншими економічними категоріями, що робить його визначення досить суперечливим. Інвестиційний потенціал варто розглядати за складовими елементами як сукупну взаємодію двох понять: «інвестиції» та 
«потенціал».

Загалом, інвестиційний потенціал - це системна єдність забезпечення процесів формування та ефективного використання власних і залучених інвестиційних ресурсів, що зумовлена природними, економічними і соціальними умовами країни та спрямована на сталий розвиток держави. Для характеристики інвестиційного потенціалу розглянемо джерела його формування (рис. 1).

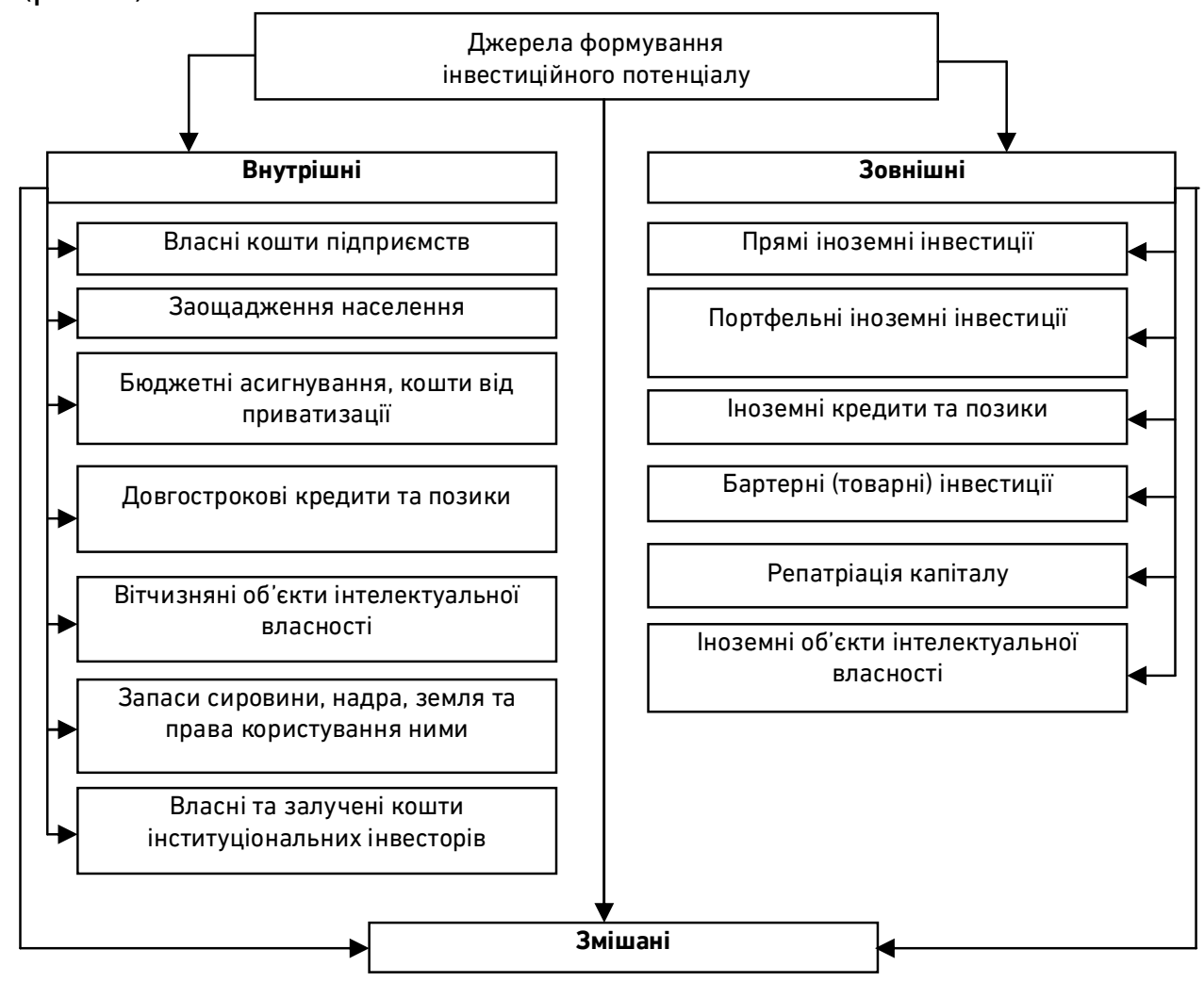

Рис. 1. Джерела формування інвестиційного потенціалу Джерело: узагальнено автором на основі $[1 ; 6 ; 7 ; 8]$

Як бачимо 3 рис. 1, одним із найважливіших внутрішніх інвестиційних ресурсів країни $\epsilon$ заощадження населення. Найчастіше під заощадженнями розуміють систему економічних відносин між суб'єктами з приводу формування, збереження та використання грошових коштів та фінансових ресурсів. 3 точки зору економічної теорії, заощадження - це різниця між доходами та витратами на споживання, а точніше, невикористання частини доходу на споживання [7, С. 106].

На думку Бадіди М.П. та Жука І.І., заощадження виступають частиною грошових доходів населення, що формуються внаслідок скорочення поточного особистого споживання і призначені для 
забезпечення потреб у майбутньому. Рівень доходів населення обмежує величину можливого задоволення потреб громадян і зумовлює потребу нагромаджувати гроші, щоб придбати потрібний товар або сплатити послугу у наступних періодах [2, С. 27].

Теорія абсолютного доходу Дж. М.Кейнса визначає, що 3 ростом доходів населення в основному збільшуються і заощадження, а споживання зростає не так стрімко. Зі зменшенням доходів, насамперед, скорочуються заощадження, а споживання залишається приблизно на тому ж рівні [5]. А в описі відносного доходу Дж. Дюзенберрі йдеться про те, що при зміні рівня доходів населення заощадження і споживання змінюються в рівних пропорціях [1].

Ми поділяємо наведену вище думку авторів, що заощадження населення являють собою частину доходу, який залишається у формі тимчасово вільних грошових коштів після здійснення споживчих витрат. Разом з тим, заощадження варто розглядати як капітал, який використовується для збільшення доходу у майбутньому. Будь-який зовнішній мотив накопичення заощаджень - це приріст капіталу, який супроводжується певними ризиками з боку вкладників, пов'язаними з розміщенням грошей в ощадних інститутах.

Заощадження населення можуть втілюватись у різних активах - ощадних інструментах, які можна класифікувати як за видами, так і за формами (рис. 2). Загалом заощадження поділяють на два основних види: супутні, які представлені резервами засобів обігу і платежу та самостійні заощадження. Самостійні заощадження за формою розміщення тимчасово вільних грошових коштів поділяються на організовані (вкладаються в інструменти фінансових інститутів, що функціонують на різних сегментах фінансового ринку) та неорганізовані (формуються населенням самостійно, без участі фінансових інститутів, наприклад, готівка в національній та іноземній валютах) [4, С. 109]. Для населення будь-яка організована форма заощаджень буде інвестицією, оскільки від розміщення заощаджень у фінансових інститутах населення отримує прибуток у вигляді відсотків і дивідендів.

За формою розміщення тимчасово вільних грошових коштів

Неорганізовані заощадження можуть бути джерелом для організованих заощаджень, якщо населення прийме рішення про переведення частини неорганізованих заощаджень в організовану форму [8, С. 29]. Вибір організованої чи неорганізованої форми заощадження фінансових активів обумовлений дією багатьох факторів, зокрема: ступенем довіри до кредитно-фінансових установ, прибутковістю різних інструментів фінансового ринку, можливістю оперативного вилучення заощаджень або переведення 3 однієї 


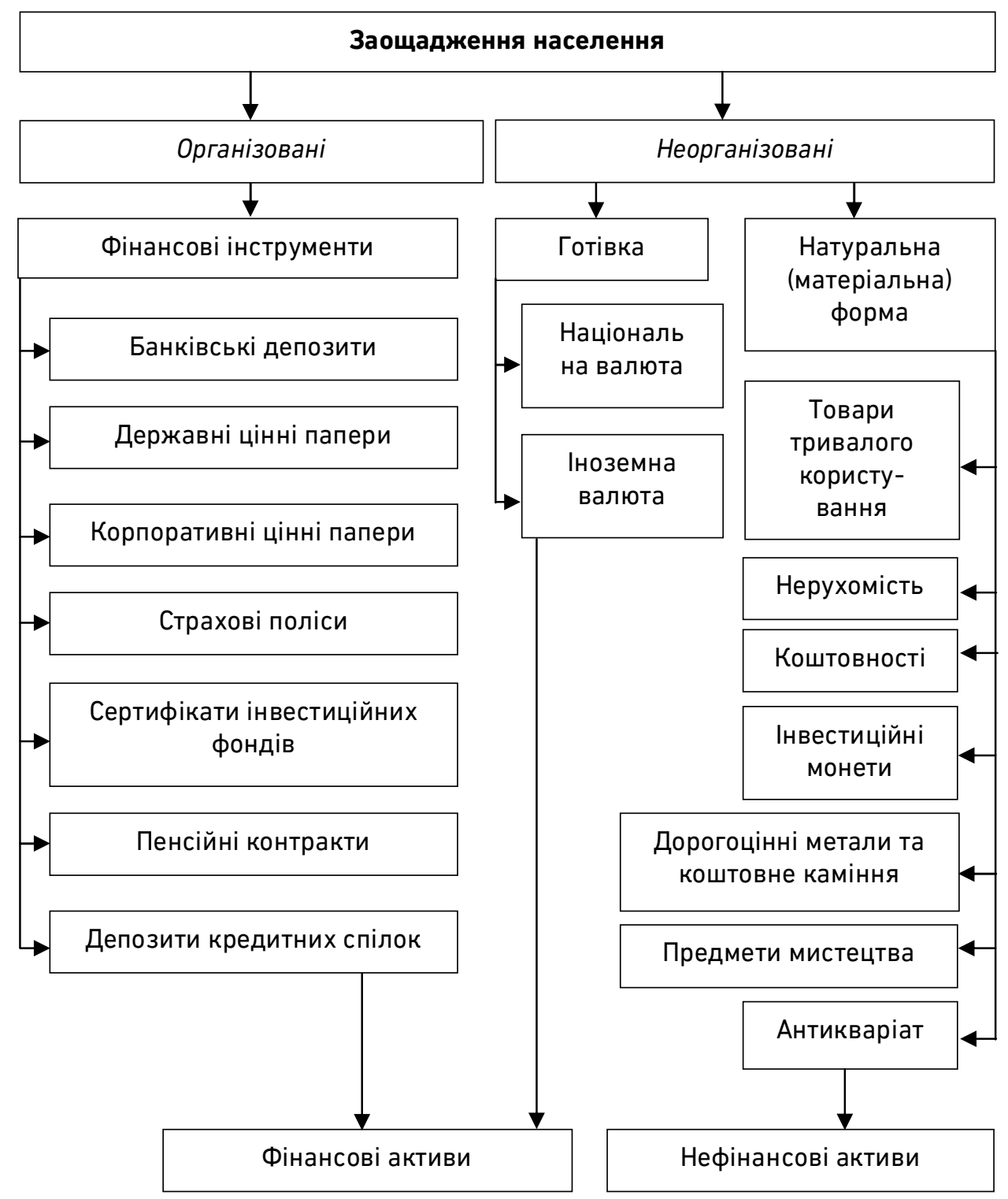

Рис. 2. Класифікація заощаджень населення за формою активів Джерело: узагальнено автором на основі $[4 ; 6 ; 8]$

Передумовою формування ощадної поведінки населення, що впливає на рівень інвестиційного потенціалу в країні, виступають основні показники соціально-економічного розвитку України, представлені у табл. 1. 
Таблиця 1

Основні соціально-економічні показники України за 2017-2019 pp. [9]

\begin{tabular}{|c|l|c|c|c|c|}
\hline $\begin{array}{c}\text { № } \\
\text { з/п }\end{array}$ & \multicolumn{1}{|c|}{ Показники } & $\begin{array}{c}\text { Одиниці } \\
\text { вимірювання }\end{array}$ & 2017 р. & 2018 р. & 2019 р. \\
\hline 1 & \multicolumn{1}{|c|}{2} & 3 & 4 & 5 & 6 \\
\hline 1. & $\begin{array}{l}\text { Валовий ВВП } \\
\text { у фактичних } \\
\text { цінах) }\end{array}$ & млрд грн & 2983,9 & 3560,6 & 3974,6 \\
\hline 2. & $\begin{array}{l}\text { Доходи } \\
\text { населення }\end{array}$ & млрд грн & 2652,1 & 3248,7 & 3699,3 \\
\hline 3. & Доходи бюджету & млрд грн & 1017 & 1184,3 & 1289,8 \\
\hline 4. & $\begin{array}{l}\text { Капітальні } \\
\text { інвестиції }\end{array}$ & млрд грн & 448,5 & 578,7 & 624 \\
\hline 5. & $\begin{array}{l}\text { Чисельність } \\
\text { постійного } \\
\text { населення }\end{array}$ & млн осіб & 42,2 & 42 & 41,7 \\
\hline 6. & $\begin{array}{l}\text { Кількість } \\
\text { зайнятих віком } \\
\text { 15-70 років }\end{array}$ & тис. осіб & 16156,4 & 16360,9 & 16578,3 \\
\hline 7. & $\begin{array}{l}\text { Середньомісячна } \\
\text { номінальна } \\
\text { заробітна плата }\end{array}$ & грн & 7104 & 8865 & 10497 \\
\hline
\end{tabular}

Як свідчать наведені дані, усі показники за період 2017-2019 pp. мають позитивну динаміку: відбувається зростання доходів населення на 39,5\%, доходів бюджету - на 26,7\%, капітальних інвестицій - на 39,1\%, середньомісячної заробітної плати - на 47,8\%.

Представлені показники дають підстави для висновку, що в країні зростає потреба в інвестиційних ресурсах і $€$ можливості для задоволення цієї потреби за рахунок внутрішніх джерел. Щодо капітальних інвестицій за видами активів в Україні, слід відмітити, що найбільше коштів інвестується у матеріальні активи (понад 95\% від усіх капітальних інвестицій): житлові та нежитлові будівлі, інженерні споруди, машини та обладнання.

Для більш детального вивчення інвестиційного процесу в країні, розглянемо структуру капітальних інвестицій за джерелами фінансування за 2019 рік (рис. 3). 


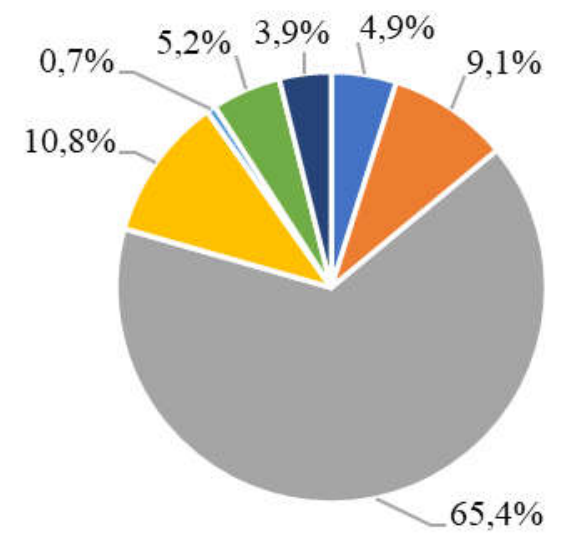

" кошти державного бюджету

" кошти місцевих бюджетів

" власні кошти підприємств та організацій

" кредити банків та інші позики

= кошти інвесторів-нерезидентів

" кошти населення на

будівництво житла

- інші джерела фінансування

Рис. 3. Структура капітальних інвестицій за джерелами фінансування у 2019 p. [9]

Очевидно, що найбільша частка капітальних інвестицій фінансується за рахунок власних коштів підприємств та організацій $(65,4 \%)$, а найменша - за рахунок коштів інвесторів-нерезидентів (0,7\%). Другими по питомій вазі ресурсами, які використовуються для капітальних інвестицій, є кредити банків та інші позики (у 2019 р. їх частка склала 10,8\%).

Зауважимо, що в структурі депозитів, залучених банками, та використовуваних у якості кредитних ресурсів, найбільшу частку займають заощаджені кошти населення. Відтак, ці нагромаджені кошти населення банк перетворює у позичковий капітал, який надається в позику власникам на умовах повернення та платності. Тому депозитна політика банку повинна бути взаємопов'язаною із його кредитною політикою і забезпечувати реалізацію останньої.

Проаналізуємо динаміку основних банківських резервів (кредитів та депозитів) і визначимо їх співвідношення, яке дозволить нам виявити ступінь забезпеченості кредитних коштів депозитними. Це співвідношення відоме також як індекс LTD (loan-to-deposit ratio).

3 рис. 4 видно, що динаміка обсягу наданих кредитів банками $\epsilon$ негативною. У 2018 р. обсяг кредитів зріс на 56474 млн грн (або на 5,6\%) порівняно з 2017 р., а у 2019 р. порівняно з 2018 р., навпаки, зменшився на 101260 млн грн (або на 9,4\%).

Динаміка обсягу депозитів населення $€$ більш позитивною i щороку відбувається збільшення даного показника. У 2018 р. обсяг депозитів збільшився на 34123 млн грн (або на 3,8\%) порівняно 3 2017 р., а у 2019 р. зріс ще на 138699 млн грн (або на 14,9\%) порівняно $з 2018$ р. Найбільше депозитів залучено банками за 
рахунок коштів домашніх господарств, питома вага яких становить понад 50\% від загального обсягу залучених депозитів.

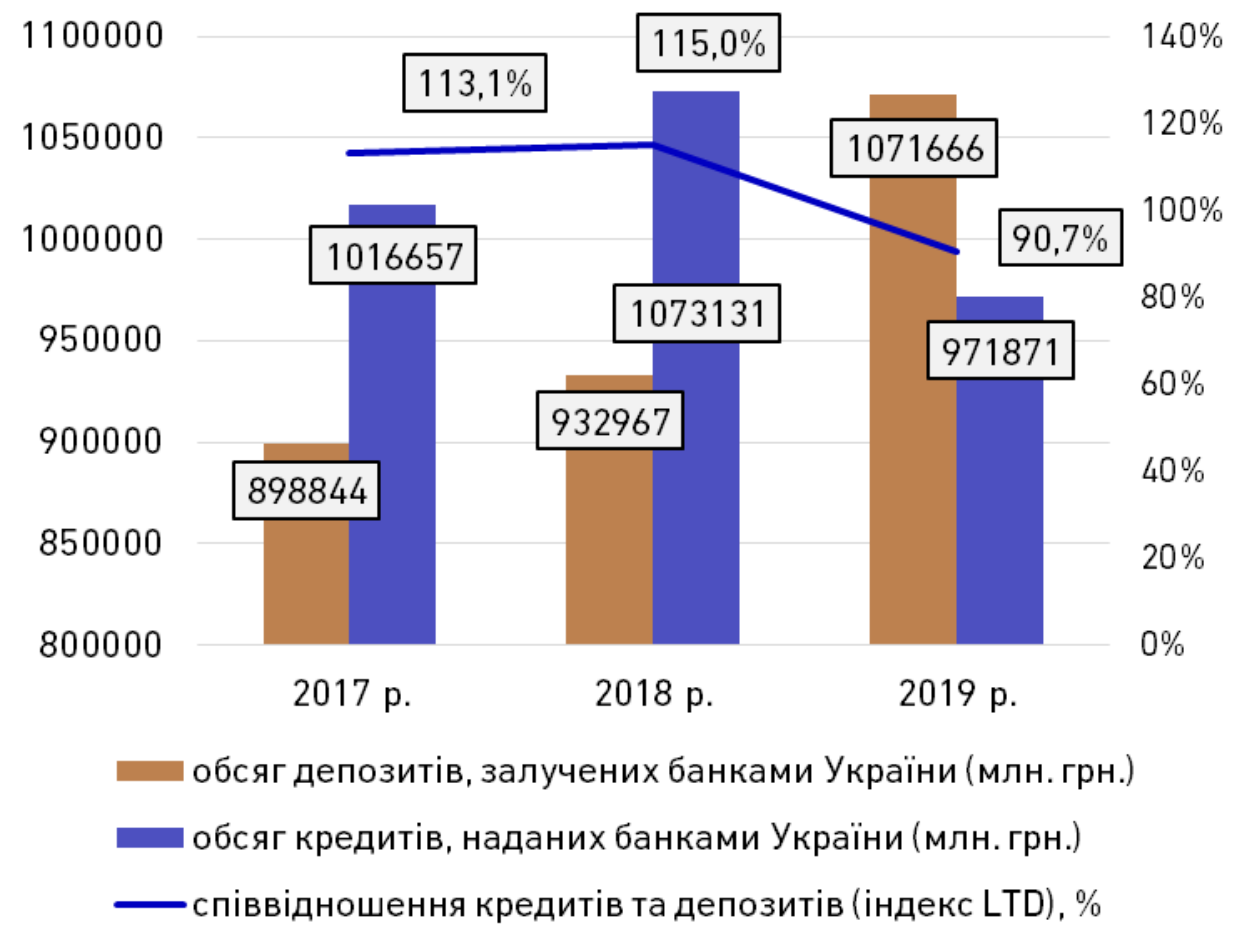

Рис. 4. Співвідношення кредитів та депозитів банківської системи України у 2017-2019 рp. [10]

Загалом оптимальне значення індексу співвідношення кредитних та депозитних ресурсів банку має дорівнювати 100\%, що буде свідчити про збалансованість цих ресурсів. Отже, динаміка індексу LTD в Україні за 2017-2018 рр. свідчить про наявність розбалансованості ринку кредитно-депозитних послуг, оскільки обсяг наданих позик суттєво перевищує обсяги коштів на депозитних рахунках. Це може означати, що за 2017-2018 рр. вітчизняні банки активно позичали гроші на міжбанківському ринку, один в одного, а згодом і перепозичали своїм клієнтам, проте за вищими ставками. Подібні дисбаланси природно зменшують фінансову стійкість банку.

Зазначене засвідчує, що в таких умовах має суттєво підвищитись роль державних органів у стимулюванні та посиленні мотивації населення до здійснення організованих заощаджень. Серед таких напрямків можна запропонувати:

- підвищення фінансового потенціалу населення шляхом активізації його економічної поведінки; 
- посилення стимулюючої функції податків;

- розширення легальних джерел додаткових доходів;

- підтримки підприємницької діяльності;

- реалізації механізмів соціального захисту;

- повернення довіри громадян до фінансового сектора економіки, управління ризиками та мінімізацію трансакційних витрат в умовах кризи та нестабільності економічного розвитку;

- розвиток системи страхування заощаджень та гарантування збереження вкладів;

- створення мотиваційних передумов до заощадження.

Узагальнюючи вищезазначене, можна зробити висновок, що модернізація економічної системи України повинна спиратися на власні внутрішні інвестиційні джерела країни, і це насамперед заощадження населення. Участь населення в інвестиційноощадному процесі є одним з факторів не тільки покращення рівня життя в країні, але і показником певної зрілості та стабільності фінансового ринку.

1. Inflation and the Consumer / Juster F. T., Wachtel P., Hymans S., Duesenberry J. Brookings Papers on Economic Activity. 1972. No. 1. Рp. 71-121. 2. Бадіда М. П., ЖукІ.І. Концептуальні засади фінансового забезпечення реалізації регіональної політики. Бізнес/нформ. 2014. № 4. С. 41. 3. Аналітичного центру «Академія»: вебсайт. URL: http://www.academia.org.ua (дата звернення: 05.11.2020). 4. Доходи i заощадження населення в перехідній економіці України : монографія / за ред. С. Панчишина, М. Савлука. Львів : Вид-во ЛнУ ім. Івана Франка, 2003. 406 с. 5. Кейнс Дж. М. Общая теория занятости, процента и денег. Москва : Прогресс, 1992. 520 с. 6. Кузів І. В. Пріоритетні напрями інвестування заощаджень домашніх господарств в Україні. Формування ринкових відносин в Україні. 2007. № 10 (77). С. 68-72. 7. Макконелл К. Р., Брю С. Л. Экономикс : принципы, проблемы и політика : в 2 т. Киев : ХагарДемос, 1993. С. 106. 8. Палиця С. В., Федоренко М. С. Вкладення заощаджень населення України в інвестиції. Інвестиції: практика та досвід. 2010. № 23. С. 28-29. 9. Статистичний щорічник України за 2019 рік. / за ред. Ю. В. Мороза. Рівне : Головне управління статистики України, 2019. 409 с. 10. Статистичний бюлетень НБУ. URL: http://www.bank.gov.ua/Statist/electronic\%20bulletin/el__bul_102008.pdf (дата звернення: 10.11.2020).

\section{REFERENCES:}

1. Inflation and the Consumer / Juster F. T., Wachtel P., Hymans S., Duesenberry J. Brookings Papers on Economic Activity. 1972. No. 1. Pp. 71-121. 2. Badida M. P., Zhuk I. I. Kontseptualni zasady finansovoho zabezpechennia realizatsii rehionalnoi polityky. Biznes/nform. 2014. № 4. S. 41. 3. Analitychnoho tsentru «Akademiia»: vebsait. URL: http://www.academia.org.ua (data zvernennia: 05.11.2020). 4. Dokhody i zaoshchadzhennia naselennia $v$ perekhidnii ekonomitsi Ukrainy : monohrafiia / za red. S. Panchyshyna, M. Savluka. Lviv : Vyd-vo LNU im. Ivana Franka, 2003. 406 s. 5. Keyns Dj. M. Obschaya teoriya zanyatosti, protsenta i deneg. Moskva : Progress, 
1992. 520 s. 6. Kuziv I. V. Priorytetni napriamy investuvannia zaoshchadzhen domashnikh hospodarstv v Ukraini. Formuvannia rynkovykh vidnosyn v Ukraini. 2007. № 10 (77). S. 68-72. 7. Makkonell K. R., Bryu S. L. Ekonomiks : printsipyi, problemyi i politika : v 2 t. Kiev: HagarDemos, 1993. S. 106. 8. Palytsia S. V., Fedorenko M. S. Vkladennia zaoshchadzhen naselennia Ukrainy $\mathrm{v}$ investytsii. Investytsii: praktyka ta dosvid. 2010. № 23. S. 28-29. 9. Statystychnyi shchorichnyk Ukrainy za 2019 rik. / za red. Yu. V. Moroza. Rivne : Holovne upravlinnia statystyky Ukrainy, 2019. 409 s. 10. Statystychnyi biuleten NBU. URL: http://www.bank.gov.ua/Statist/electronic\%20bulletin/el__bul_102008.pdf (data zvernennia: 10.11.2020).

Melnyk L. M. [1; ORCID ID: 0000-0003-1731-1860], Candidate of Economics (Ph.D.), Associate Professor, Duma V. L. ${ }^{[2]}$, Candidate of Economics (Ph.D.), Manager, Yakovchuk O. V. ${ }^{[1]}$, Graduate Student

${ }^{1}$ National University of Water and Environmental Engineering, Rivne ${ }^{2}$ Commercial bank «Privatbank», Rivne

\section{ROLE OF POPULATION SAVINGS IN THE FORMATION OF THE INVESTMENT POTENTIAL OF THE COUNTRY}

The solution to the problem of forming internal sources of investment is impossible without the mobilization of free monetary resources of the population. Therefore, the urgent task facing the domestic economy is the accumulation of free money of the population, the development of an effective mechanism for their transformation into an investment resource to ensure long-term lending to the manufacturing sector.

The purpose of this article is to substantiate the theoretical and practical principles of the formation of savings and their impact on the investment potential of the country. The article considers the theoretical and methodological aspects of the formation of the investment potential of the country, which means the process of formation and effective use of own and attracted investment resources. Internal, external and mixed sources of investment resources formation are singled out. It is determined that the savings of the population are part of the income that remains in the form of temporarily free money after the implementation of consumer spending. It is noted that savings should be considered as capital that is used to increase income in the future. The classification of savings depending on the forms (organized and unorganized) and financial instruments. Financial instruments in the organized form of savings include bank deposits, 
government and corporate securities, insurance policies, investment fund certificates, pension contracts.

The preconditions for the formation of frugal behavior of the population are analyzed and it is established that the need for investment resources is growing in the country and there are opportunities to meet this need at the expense of domestic sources. The structure of capital investments by sources of financing is investigated. It is determined that the largest share of capital investments is financed by own funds of enterprises and bank loans. The dynamics of the main bank reserves has been analyzed and the degree of security of credit funds by deposits has been determined. Proposals to improve the mechanism of population savings in order to increase the country's investment potential have been provided.

Keywords: savings of the population; income of the population; investment potential; capital investments; bank deposits.

Мельник Л. М. ${ }^{[1 ;}$ ORCID ID: 0000-0003-1731-1860] к.э.н., доцент,

Дума В. Л. ${ }^{[2]}$, к.э.н., менеджер

Яковчук О. В. ${ }^{[1]}$, соискатель высшего образования второго (магистерского) уровня

${ }^{1}$ Национальный университет водного хозяйства и природопользования, г. Ровно ${ }^{2}$ Коммерческий банк «Приватбанк», г. Ровно

\title{
РОЛЬ СБЕРЕЖЕНИЙ НАСЕЛЕНИЯ В ФОРМИРОВАНИИ ИНВЕСТИЦИОННОГО ПОТЕНЦИАЛА СТРАНЫ
}

\begin{abstract}
В статье рассмотрены теоретико-методические аспекты формирования инвестиционного потенциала страны. Выделены внутренние, внешние и смешанные источники финансирования инвестиционных ресурсов. Определена сущность сбережений населения и проведена их классификация в зависимости от форм и финансовых инструментов. Проанализированы предпосылки формирования сберегательного поведения населения. Исследована структура капитальных инвестиций в зависимости от источников финансирования. Даны предложения по улучшению механизма формирования сбережений населения для расширения инвестиционного потенциала страны.

Ключевые слова: сбережения населения; доходы населения; инвестиционный потенциал; капитальные инвестиции; банковские депозиты.
\end{abstract}

